\title{
Non-adherence to Preventive Behaviours During the COVID-19 Epidemic: Findings From a Community Study
}

Róbert Urbán ( $\square$ urban.robert@ppk.elte.hu )

Eötvös Loránd University

\section{Borbála Paksi}

Eötvös Loránd University

\section{Ádám Miklósi}

Eötvös Loránd University

John B. Saunders

University of Queensland

\section{Zsolt Demetrovics}

Eötvös Loránd University

\section{Research Article}

Keywords: adherence, preventive behaviours, SARS-CoV-2, COVID-19, hygienic behaviour

Posted Date: February 17th, 2021

DOl: https://doi.org/10.21203/rs.3.rs-209275/v1

License: (9) This work is licensed under a Creative Commons Attribution 4.0 International License. Read Full License

Version of Record: A version of this preprint was published at BMC Public Health on July 28th, 2021. See the published version at https://doi.org/10.1186/s12889-021-11506-0. 


\section{Abstract}

Backgrounds: Preventive behaviours are an essential way to slow down and eliminate the transmission of SARS-CoV-2. The aim of this study was to estimate adherence to preventive behaviors and to identify whether any subgroups were not adopting these behaviours and for whom greater engagement in these approaches was indicated.

Methods: In this cross-sectional study, we obtained data from a random sample of a panel representing men and women of adult age residing in Hungary $(N=5,254)$. The survey included questions about the frequencies of preventive behaviours, perceived susceptibility and severity of COVID-19.

Results: We found four factors of preventive behaviours: using physical barriers (mask and gloves), avoidance of close contacts, personal hygiene, and preparation. We identified two broadly adherent groups (36.8\% and $45.3 \%$ ) and two non-adherent groups (13.1\% and $4.8 \%)$. Being male and being aged between 18-29 years were the strongest predictors of non-adherence. Concern about the severity of COVID-19 was a predictor of adherence.

Conclusions: To ensure maximal adherence to preventive behaviours for COVID-19, additional strategies should focus on their adoption by men and young adults.

\section{Introduction}

The pandemic of COVID-19, caused by SARS-CoV-2, represents the most rapidly spreading infectious disease since the influenza pandemic of 1918-19. Responding effectively to the COVID-19 pandemic requires the collaborative efforts of health officials of all countries. It also necessitates people worldwide changing their individual behaviours in response to the public health imperative of infection control. Consequently social and behavioural sciences play central roles in coping with the challenges caused by the current COVID-19 and future pandemics $(1,2)$.

Possible routes of transmission include close contacts between people, contracting the virus though surface spread (via fomites), contracting it via large droplets (through coughing and sneezing), and airborne (aerosol) transmission especially in enclosed spaces(3). Importantly, transmission of the SARSCoV-2 is possible from infected people who are asymptomatic(4). Preventive measures therefore need to be applied irrespective of apparent symptoms. Infectivity is assessed by the basic reproduction number (R0) (i.e. without any intervention) and is estimated to be 3.32 [2.81-3.82](5). A key goal is to decrease this number to below 1.0 through coordinated prevention efforts which requires the engagement of members of the community and their adherence to these preventive approaches. Adherence to advice on preventive behaviours may be expected to reduce the spread of infection and give opportunity to the health care system to build up appropriate resources to treat the severe cases(6). The issue is whether and how this will be achieved in a sustained way. 
Prevention of transmission of SARS-CoV-2 therefore requires behaviour change that dramatically alters human interactions, independently of economic status and cultural heritage. Countries facing the COVID19 epidemic need to and most have implemented public health interventions and legislation to decrease the frequency of close personal contact by spatial distancing(7) and to promote physical or chemical barriers to virus transmission, through wearing face masks and gloves, and hand washing, respectively. A meta-analysis of studies investigating interventions to prevent influenza provided evidence of benefit from multiple preventive behaviours(8). For example, hand washing in combination with face mask use reduces significantly influenza virus transmission(8). Countries, however, differ in which protective measures are recommended. For example, the recommendation of wearing a face mask varies across countries $(9,10)$. The degree of adherence necessary for effective prevention across populations is still not known, but we assume that consistent - every day or almost every day - use of preventive behaviours can significantly decrease the rate of viral transmission.

Understanding both distal (underlying) and proximal predictors of preventive behaviours may help predict different rates of viral submission in subgroups of the population. In most countries reporting death rates from COVID-19, these have been greater in men than women. In China and Italy deaths of men have been more than twice those of women. In New York City men constitute about 61 per cent of patients who die $(11,12)$. Men comprise $62.4 \%$ of COVID-19 deaths among those under 75 years of age in Hungary. Could it be that men are less likely to adopt preventive behaviours and more likely to become infected and die from the disease? Of course gender differences may be influenced by age, culture, other socioeconomic factors (13) or comorbidity status(11). Preventive behaviours may play a role in the social disparities in SARS-CoV-2 infection, hospitalization and mortality(14).

In practical terms, the more immediate (proximal) predictors are of crucial importance. Health beliefs and other cognitive factors may explain different levels of adherence to preventive behaviours(15). These include perceived susceptibility to, and perceived severity of the infection and its consequences. In the previous SARS pandemic, threat perception, perceived susceptibility and severity varied across countries(16). However, in this study, the link between cognitive variables and infection control or preventive behaviours was not determined.

The present study had two aims. The first aim was to estimate the pattern of preventive behaviours and adherence and non-adherence to them. Adherence was defined as the person's willingness to follow consistently those preventive behaviours which can decrease the chance of transmission of SARS-CoV-2. The second aim was to understand the role of distal factors such as gender, age, and socioeconomic status and proximal health beliefs in explaining the variance of preventive behaviours in the general population. It was hypothesized that men are less likely to adopt preventive behaviours than women. We also wished to examine in particular preventive behaviours in young people and in those of lower socioeconomic status.

\section{Methods}




\section{Participants and sampling method}

In this cross-sectional study, participants were recruited from a panel of Hungarian adults (age > 18) using a computer-assisted web interview (CAWI) involving 74,500 currently active members as a sampling frame. A one-stage probabilistic random sampling method had been applied. The sample was stratified according to gender, age, education, and domicile, by over-representing the strata with low responsiveness to ensure that the final sample represents the Hungarian adult population according to the above characteristics. The sample size is planned to reduce sampling error below 1.5\%. 5,254 participants completed the survey. To compensate for sample disproportions, an iteration weighting by layer categories was used. The socio-demographic features of the sample are presented in Table 1.

Participation of this study was anonymous and voluntary. The participants were requested to construct a code which made it possible to contact them later for a possible follow-up data-collection. This study was performed in accordance with Helsinki declaration and approved by the Institutional Review Board of Eötvös Loránd University, Budapest, Hungary (no: 2020/134). Informed consent was obtained from all participants.

\section{Study setting}

Before the time of data collection, which began on 27 March 2020 and ended on 6 April 2020, Hungary had experienced the onset of SARS-CoV-2 transmission and COVID-19 disease (see Fig. 1). However, throughout the study, Hungary had a relatively low number of infections and a low death rate, which was seen predominantly in those over 65 years of age. The Hungarian Government declared a state of emergency on 11 March and started curfew restrictions on 28 March, which on 9 April were extended for an unlimited time.

\section{Measures}

\section{Outcomes}

Preventive behaviours: Fifteen statements were constructed to embrace a wide range of preventive behaviours including

- wearing disposable gloves,

- wearing a face mask,

- using hand sanitizer,

- hand washing,

- avoidance of facial self-touching,

- keeping at least 2 meters distance from another person,

- avoiding public transportation,

- avoiding close contacts, and 
- avoiding meetings.

The full list of questions is presented in Table 1. The response options were provided such as never (1), sometimes (2), $50 \%$ of cases or times (3), almost always (4) and always (5).

Adherence to "stay at home" message: Three questions asked the participants' behaviour during the past 7 days: how many days they left their home (1) for work, (2) for buying food and visiting a pharmacy; (3) for other reasons. The respondents had to indicate the number of days over the past 7 days.

\section{Predictors}

Perceived susceptibility. Six questions enquired about the likelihood of (a) contracting the virus without knowing it; (b) contracting the virus and having no or mild symptoms; (c) mild suffering from the infection; (d) contracting the infection and being placed in quarantine; (e) getting hospitalized due to the infection; (f) getting into the intensive care unit in a hospital. Responses were recorded on a 5-point from unlikely (1) to very likely (5). Based on the item correlations, the principal component analysis revealed two factors, namely (i) likelihood of being asymptomatic or having mild symptoms and (ii) likelihood of severe conditions due to coronavirus (explained variance $=76.9 \%$ ). In further analyses, we used these two factors: perceived likelihood of being asymptomatic or having mild symptoms (Cronbach $a=.74$ ), and perceived likelihood of a severe condition (Cronbach $a=.88$ ). Two scores summated the mean of the relevant items.

Perceived severity: Four questions were constructed to measure the perceived impact of novel coronavirus infection on individual and family health. Responses were recorded on a 5-point Likert type scale from not at all (1) to very much (5). The principal component analysis revealed one component (explained variance $=76.9 \%$ ). The scale score was calculated with the mean of the responses (Cronbach $a=0.85)$.

Cues to action: Two questions assessed cues to preventive actions: (1) in the household, how many people are vulnerable to severe coronavirus infection; (2) if the participant suffers from any chronic health condition.

\section{Statistical analysis}

Beyond the descriptive statistics, the following analyses were determined by the data analysis strategy:

(1) An exploratory factor analysis (EFA) was carried out on the preventive behaviors in order to identify the main factors of these behaviours. The responses were used as ordinal indicators with GEOMIN (an oblique-type) rotation. Eigenvalues greater than 1, inspection of the scree plot, and interpretability of the factor solution were used in determining the number of extracted factors. Based on the factor solution, scale scores were calculated by averaging the items belonging to each factor.

(2) We aimed to identify groups of people exhibiting similar patterns of preventive behaviour to detect the proportion of people who are less prone to COVID-19 due to consistent use of preventive measures. A 
latent profile analysis was therefore performed with preventive behaviour factors as observed indicators. The latent profile analysis (17) is a latent variable analysis with a categorical latent variable - in this case adherence types - and continuous manifest indicators such as preventive behaviour factors. In the process of determining the number of latent classes, the Bayesian information criteria was used, alongside the interpretability of clusters. Furthermore, the Lo-Mendell-Rubin Adjusted Likelihood Ratio Test was also used. This compares the estimated model with a model having one less class than the estimated model. A low $p$ value $(<.05)$ indicates that the model with one less class is rejected in favor of the estimated model.

(3) We compared the latent classes using the most likely class membership across distal sociodemographic variables and the proximal variables such as health beliefs, cues to action and finally we also used the behavioural indicators of the degree of following the "stay at home" message to validate concurrently our classes.

(4) Finally, we merged the non-adherent groups and the adherent groups and performed two-step hierarchical binary logistic regression: in the first step we entered the distal explanatory variables and then in the second step we also add the proximal explanatory variables.

All analyses were performed with SPSS 22 (IBM SPSS Inc., Chicago, Illinois) and MPlus 8.0 program(18). The data that support the findings of this study and the used Mplus syntax files are available from the corresponding author upon reasonable request.

\section{Results}

\section{Descriptive statistics}

The descriptive statistics are presented in Table 1. The most frequently used preventive behaviours were hand washing and avoiding different types of close contact with other people. Consistent gender differences were detected: males performed preventive behaviours less often than females (Table 1) with effect sizes mostly in the medium range. Men left home for specified and unspecified reasons more frequently than women.

Table 1. Descriptive statistics and sex difference. 


\section{Total Males Females t-test $/ \chi^{2}$}

Demographic variables ${ }^{a}$

Sex, Females N (\%)

3247

(61.8)

Age, Mean (SD)

53.8

(14.4)

56.38

(14.19)

52.25

(14.37)

$10.15^{\star \star \star} \quad 0.29$

Education:

Less than high school $N(\%)$

683

(13.0)

319

(15.9)

364

(11.2)

$42.1^{\star * *}$

$0.09^{\#}$

High school $N(\%)$

$\begin{array}{lll}2374 & 807 & 1567 \\ (45.2) & (40.2) & (48.3)\end{array}$

College or University $N(\%)$

$\begin{array}{lll}2197 & 881 & 1316 \\ (41.8) & (43.90) & (40.50)\end{array}$

Settlement type

Budapest (capital)

952

(18.1)

County-town

940

(17.9)

Other city

$\begin{array}{lll}1787 & 596 & 889 \\ (34.0) & (29.7) & (27.4)\end{array}$

(34.0)

(29.7)

(18.5)

514

(15.8)

$14.2^{\text {** }}$

1322

(40.7)

729

310

1575

(30.0)

(15.4)

522

(16.1)

Having any chronic disease $N(\%)^{\mathrm{b}}$

Preventive behaviours ${ }^{c}$

Washing hands when arrived home

Avoiding contacts while greetings (hugging,

kissing)
1788

(34.0)

Always

$N(\%)$

720

(36.6)

1068

(33.4)

$5.34^{*}$

Mean

(SD)

(SD)

4583

(88.7)

\subsection{0}

$(0.79)$

4.88

$(0.50)$

4334

(83.5)

4.68
$(0.84)$

4.68
$(0.84)$

4.74

$(0.74)$

\begin{tabular}{|c|c|}
\hline $10.12 * \star *$ & 0.29 \\
\hline $2.73^{\star \star \star}$ & 0.08 \\
\hline
\end{tabular}

Note: Data are presented without the sampling weights. \#: Phi coefficient. ${ }^{* \star} p<0.001 ; * \star p<0.01$. Boldfaced t-values are still significant after the Bonferroni correction of multiple testing $(p<.002)$. ${ }^{a}$ : No missing value. ${ }^{b}$ : Number of missing values is $89(1.7 \%)$. ${ }^{\text {. }}$ Numbers of missing or no responses were between $28(0.5 \%)$ and $114(2.1 \%)$. ${ }^{\mathrm{d}}$ : Number of missing values is $48(0.9 \%)$. ${ }^{\mathrm{e}}$. Numbers of missing values are between $12(0.2)$ and 68 (1.3). 


\begin{tabular}{|c|c|c|c|c|c|}
\hline & Total & Males & Females & t-test $/ \chi^{2}$ & $\begin{array}{l}\text { Effect } \\
\text { size - } \\
\text { Cohen } \\
\text { d }\end{array}$ \\
\hline Avoiding handshake & $\begin{array}{l}4061 \\
(78.4)\end{array}$ & $\begin{array}{l}4.49 \\
(0.96)\end{array}$ & $\begin{array}{l}4.77 \\
(0.70)\end{array}$ & $13.60 * * *$ & 0.39 \\
\hline Avoiding meeting with group of people & $\begin{array}{l}3932 \\
(75.8)\end{array}$ & $\begin{array}{l}4.41 \\
(1.10)\end{array}$ & $\begin{array}{l}4.68 \\
(0.80)\end{array}$ & $10.07 * \star \star$ & 0.29 \\
\hline Avoiding public transportation & $\begin{array}{l}3691 \\
(71.7)\end{array}$ & $\begin{array}{l}4.35 \\
(1.22)\end{array}$ & $\begin{array}{l}4.44 \\
(1.13)\end{array}$ & $2.63^{\star *}$ & 0.08 \\
\hline Washing hand when outside home & $\begin{array}{l}3581 \\
(69.3)\end{array}$ & $\begin{array}{l}4.29 \\
(1.10)\end{array}$ & $\begin{array}{l}4.58 \\
(0.92)\end{array}$ & $10.30 * \star *$ & 0.30 \\
\hline $\begin{array}{l}\text { Staying home, and leaving home only when it } \\
\text { is necessary }\end{array}$ & $\begin{array}{l}3458 \\
(66.8)\end{array}$ & $\begin{array}{l}4.29 \\
(1.06)\end{array}$ & $\begin{array}{l}4.62 \\
(0.78)\end{array}$ & $12.67 * * *$ & 0.35 \\
\hline $\begin{array}{l}\text { Avoiding people who have high risk of } \\
\text { complication (old people) }\end{array}$ & $\begin{array}{l}3343 \\
(64.4)\end{array}$ & $\begin{array}{l}4.31 \\
(1.07)\end{array}$ & $\begin{array}{l}4.50 \\
(0.92)\end{array}$ & $6.93^{* * *}$ & 0.19 \\
\hline Taking vitamin supplementation & $\begin{array}{l}2873 \\
(55.0)\end{array}$ & $\begin{array}{l}3.82 \\
(1.44)\end{array}$ & $\begin{array}{l}4.13 \\
(1.31)\end{array}$ & $8.21 * \star \star$ & 0.23 \\
\hline Using hand sanitizer & $\begin{array}{l}2285 \\
(44.4)\end{array}$ & $\begin{array}{l}2.89 \\
(1.73)\end{array}$ & $\begin{array}{l}3.71 \\
(1.65)\end{array}$ & $17.20 * \star *$ & 0.49 \\
\hline Keeping at least 2 meters distance from others & $\begin{array}{l}2043 \\
(39.6)\end{array}$ & $\begin{array}{l}3.86 \\
(1.16)\end{array}$ & $\begin{array}{l}4.14 \\
(1.00)\end{array}$ & $9.41^{* \star *}$ & 0.27 \\
\hline Avoiding self-touching (face, mouth, eyes) & $\begin{array}{l}2067 \\
(39.3)\end{array}$ & $\begin{array}{l}3.76 \\
(1.22)\end{array}$ & $\begin{array}{l}4.16 \\
(1.02)\end{array}$ & $12.83^{* * *}$ & 0.37 \\
\hline Wearing face mask & $\begin{array}{l}1043 \\
(20.3)\end{array}$ & $\begin{array}{l}2.42 \\
(1.56)\end{array}$ & $\begin{array}{l}2.73 \\
(1.65)\end{array}$ & $6.67 * \star \star$ & 0.19 \\
\hline Wearing protective gloves & $\begin{array}{l}1021 \\
(19.9)\end{array}$ & $\begin{array}{l}2.37 \\
(1.51)\end{array}$ & $\begin{array}{l}2.79 \\
(1.64)\end{array}$ & $9.20 * \star \star$ & 0.26 \\
\hline Storing food & $\begin{array}{l}540 \\
(10.3)\end{array}$ & $\begin{array}{l}2.44 \\
(1.34)\end{array}$ & $\begin{array}{l}2.64 \\
(1.40)\end{array}$ & $5.11 * \star \star$ & 0.15 \\
\hline $\begin{array}{l}\text { Having someone in the household who are at } \\
\text { risk of developing severe condition }{ }^{\text {d }}\end{array}$ & $\begin{array}{l}3205 \\
(60.0)\end{array}$ & $\begin{array}{l}1262 \\
(62.9)\end{array}$ & $\begin{array}{l}1862 \\
(57.3)\end{array}$ & $15.76 * \star \star$ & 0.11 \\
\hline $\begin{array}{l}\text { Number of days left home for work during the } \\
\text { last } 7 \text { days }{ }^{\mathrm{e}}\end{array}$ & $\begin{array}{l}2.88 \\
(2.40)\end{array}$ & $\begin{array}{l}3.32 \\
(2.56)\end{array}$ & $\begin{array}{l}2.62 \\
(2.26)\end{array}$ & $10.34 * * *$ & 0.30 \\
\hline
\end{tabular}

Note: Data are presented without the sampling weights. \#: Phi coefficient. $* \star \star x<0.001 ; * \star p<0.01$. Boldfaced t-values are still significant after the Bonferroni correction of multiple testing $(p<.002)$. ${ }^{\text {a }}$ No missing value. ${ }^{b}$ : Number of missing values is $89(1.7 \%)$. ${ }^{\text {. }}$ Numbers of missing or no responses were between $28(0.5 \%)$ and $114(2.1 \%)$. ${ }^{\mathrm{d}}$ : Number of missing values is $48(0.9 \%)$. ${ }^{\mathrm{e}}$. Numbers of missing values are between $12(0.2)$ and 68 (1.3). 


\begin{tabular}{|c|c|c|c|c|c|}
\hline & Total & Males & Females & t-test/ $\chi^{2}$ & $\begin{array}{l}\text { Effect } \\
\text { size - } \\
\text { Cohen } \\
\text { d }\end{array}$ \\
\hline $\begin{array}{l}\text { Number of days left home for shopping, } \\
\text { pharmacy during the last } 7 \text { days }^{e}\end{array}$ & $\begin{array}{l}3.02 \\
(1.81)\end{array}$ & $\begin{array}{l}3.37 \\
(1.97)\end{array}$ & $\begin{array}{l}2.80 \\
(1.67)\end{array}$ & $11.17 * \star \star$ & 0.32 \\
\hline $\begin{array}{l}\text { Number of days left home for other reasons } \\
\text { during the last } 7 \text { days }^{e}\end{array}$ & $\begin{array}{l}1.83 \\
(1.66)\end{array}$ & $\begin{array}{l}2.01 \\
(1.80)\end{array}$ & $\begin{array}{l}1.72 \\
(1.55)\end{array}$ & $6.14^{\star \star \star}$ & 0.18 \\
\hline \multicolumn{6}{|c|}{$\begin{array}{l}\text { Note: Data are presented without the sampling weights. \#: Phi coefficient. } * \star \star p<0.001 ; * \star p<0.01 \text {. } \\
\text { Boldfaced t-values are still significant after the Bonferroni correction of multiple testing }(p<.002) . \text { a. } \\
\text { No missing value. b: Number of missing values is } 89(1.7 \%) \text {. c: Numbers of missing or no responses } \\
\text { were between } 28(0.5 \%) \text { and } 114(2.1 \%) \text {. d: Number of missing values is } 48(0.9 \%) \text {. }{ }^{\text {e: Numbers of }} \\
\text { missing values are between } 12(0.2) \text { and } 68(1.3) \text {. }\end{array}$} \\
\hline
\end{tabular}

\section{Measuring preventive behaviours and identifying adherence types}

We performed exploratory factor analyses to explain the covariances among the preventive behaviours. The detailed description of the exploratory factor analysis (EFA) and factor loadings are to be found in the supplement of the present paper. Our analyses yielded four factors: (1) using a physical barrier such as wearing a face mask and protective gloves; (2) avoidance of close contacts such as avoiding hugging/kissing, shaking hands, avoidance of meetings, and avoidance of people who are at high risk; (3) personal hygienic behaviours such as hand washing, hand sanitizers, avoidance of self-touching, and keeping 2 meters distance from other people; (4) preparation including vitamin intake and storing food. The correlations among these factors ranged between 0.30 and 0.55 (Table 1).

Based on the EFA, the means of items within their respective factors were calculated and used as observed indicators in the latent profile analysis. Single- to 5-class solutions were estimated. The decision regarding the number of classes is documented in the supplemental Table 2. A four-class solution was retained (Fig. 2). According to our operationalization, adherence to preventive behaviours is defined as performing the behaviour almost always or always, which required the range of mean score to be between 4 and 5. Below this value we regarded as limited adherence or non-adherence. The most adherent class (Class 1 - Full adherence) comprised $36.8 \%$ of the sample. This class showed consistent use of all four preventive behaviours. The averaged ratings fell between always and almost always in spatial distancing, physical barriers and personal hygienic behaviours. The second most adherent class (Class 2 - Partial adherence) comprised $45.3 \%$ of people. The members of this group used spatial distancing and personal hygienic behaviours always or almost always, but they used physical barriers (mask and gloves) less frequently. The third class (Class 3 - Limited adherence) represented $13.1 \%$ of the participants. This group is characterized by the use of spatial distancing and personal hygienic 
behaviours around half of all occasions; however, this group hardly uses physical barriers. Finally, the fourth class (Class 4 - Non-adherence) represented $4.8 \%$ of people. This group did not follow the recommended actions regularly, they mentioned only the occasional use of personal hygienic behaviours to prevent coronavirus infection.

\section{Characteristics and validation of the adherence typology}

The latent classes were compared along distal demographic and proximal health belief variables (Table 2). The full adherence group (Class 1 ) differed in most characteristics from the other three groups, being characterized by higher mean age, higher proportion of women, reporting stronger perceived severity of COVID-19, higher perceived susceptibility to a serious condition, and higher rates of having someone who is vulnerable to the serious impact of COVID-19, and having at least one chronic health condition. The partial adherence group (Class 2) differed in most of the above characteristics from the full adherence group, however in some characteristics (i.e., proportion of women, perceived severity of COVID-19) showed an in-between position compared to the other two groups. The limited adherence (Class 3 ) and the non-adherent (Class 4) groups are similar in age and gender distribution by representing younger age groups and higher proportions of men compared to the other two adherent groups. These groups also reported leaving home for a reason other than work and shopping more frequently than the two more adherent groups.

Table 2. Comparisons of latent classes of preventive behaviours. 


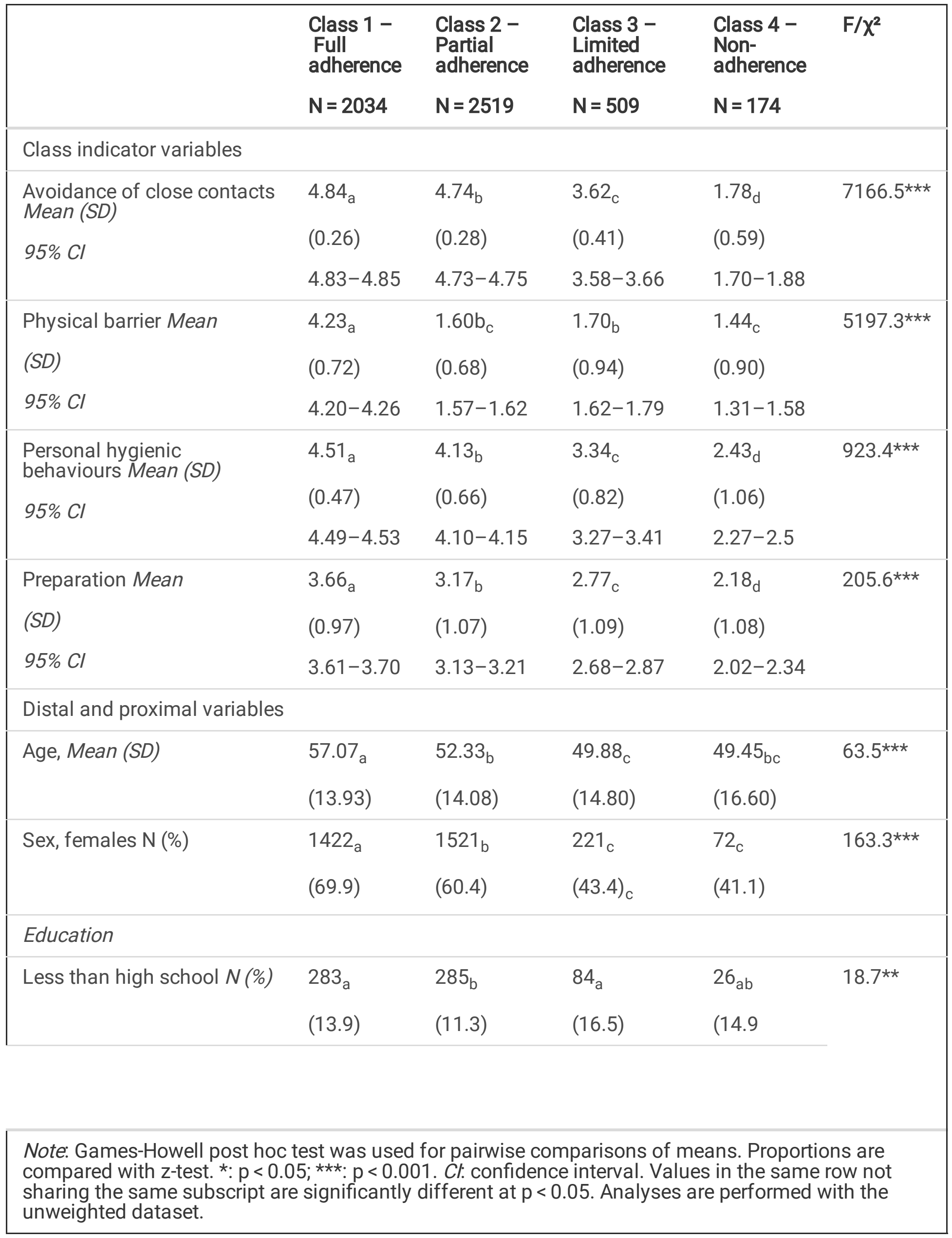




\begin{tabular}{|c|c|c|c|c|c|}
\hline & $\begin{array}{l}\text { Class } 1 \text { - } \\
\text { Full } \\
\text { adherence } \\
\text { N=2034 }\end{array}$ & $\begin{array}{l}\text { Class 2- } \\
\text { Partial } \\
\text { adherence } \\
\mathrm{N}=2519\end{array}$ & $\begin{array}{l}\text { Class } 3 \text { - } \\
\text { Limited } \\
\text { adherence } \\
\mathrm{N}=509\end{array}$ & $\begin{array}{l}\text { Class } 4 \text { - } \\
\text { Non- } \\
\text { adherence } \\
\mathrm{N}=174\end{array}$ & $F / X^{2}$ \\
\hline High school $N(\%)$ & $\begin{array}{l}933_{a} \\
(45.9)\end{array}$ & $\begin{array}{l}1124 a \\
(44.6)\end{array}$ & $\begin{array}{l}232 a \\
(45.6)\end{array}$ & $\begin{array}{l}77_{a} \\
(44.0)\end{array}$ & \\
\hline College or University $N(\%)$ & $\begin{array}{l}818 \mathrm{a} \\
(40.2)\end{array}$ & $\begin{array}{l}1110_{b} \\
(44.1)\end{array}$ & $\begin{array}{l}193_{a} \\
(37.9)\end{array}$ & $\begin{array}{l}72 \mathrm{ab} \\
(41.1)\end{array}$ & \\
\hline Settlement & & & & & \\
\hline Budapest N (\%) & $\begin{array}{l}355 \\
(17.5)\end{array}$ & $\begin{array}{l}421 \\
(16.7)\end{array}$ & $\begin{array}{l}77 \\
(15.1)\end{array}$ & $\begin{array}{l}31 \\
(17.7)\end{array}$ & 1.7 \\
\hline Health beliefs & & & & & \\
\hline $\begin{array}{l}\text { Perceived susceptibility of } \\
\text { severe condition Mean (SD) }\end{array}$ & $\begin{array}{l}2.88 \mathrm{a} \\
(1.17)\end{array}$ & $\begin{array}{l}2.65_{b} \\
(1.03)\end{array}$ & $\begin{array}{l}2.67_{\mathrm{b}} \\
(1.03)\end{array}$ & $\begin{array}{l}2.47_{\mathrm{b}} \\
(1.16)\end{array}$ & $20.1^{\star \star \star}$ \\
\hline $\begin{array}{l}\text { Perceived susceptibility of } \\
\text { asymptomatic or mild } \\
\text { condition Mean }(S D)\end{array}$ & $\begin{array}{l}3.22 \mathrm{a} \\
(0.98)\end{array}$ & $\begin{array}{l}3.37_{\mathrm{b}} \\
(0.89)\end{array}$ & $\begin{array}{l}3.38_{b} \\
(0.89)\end{array}$ & $\begin{array}{l}3.20_{a} \\
(1.14)\end{array}$ & $11.9 * \star \star$ \\
\hline $\begin{array}{l}\text { Perceived severity Mean } \\
(S D)\end{array}$ & $\begin{array}{l}4.10_{a} \\
(0.77)\end{array}$ & $\begin{array}{l}3.70_{b} \\
(0.83)\end{array}$ & $\begin{array}{l}3.53_{c} \\
(0.86)\end{array}$ & $\begin{array}{l}3.24_{d} \\
(1.15)\end{array}$ & $142.6^{\star \star \star}$ \\
\hline Cues to action & & & & & \\
\hline $\begin{array}{l}\text { Having vulnerable family } \\
\text { members in the household. } \\
\mathrm{N}(\%)\end{array}$ & $\begin{array}{l}1295 a \\
(79.3 \%)\end{array}$ & $\begin{array}{l}1421_{b} \\
(67.3)\end{array}$ & $\begin{array}{l}301_{b} \\
(71.5)\end{array}$ & $\begin{array}{l}96 \mathrm{~b} \\
(67.1)\end{array}$ & $68.2^{\star \star \star}$ \\
\hline $\begin{array}{l}\text { Having a chronic disease } \mathrm{N} \\
(\%)\end{array}$ & $\begin{array}{l}816 a \\
(40.9)\end{array}$ & $\begin{array}{l}763_{b} \\
(30.7)\end{array}$ & $\begin{array}{l}149_{b} \\
(30.1)\end{array}$ & $\begin{array}{l}56_{b} \\
(32.4)\end{array}$ & $56.6^{\star \star \star}$ \\
\hline Concurrent validation: Behav & ural indicato & during the $\mathrm{p}$ & 7 days & & \\
\hline $\begin{array}{l}\text { Number of days left home } \\
\text { for work Mean }(S D)\end{array}$ & $\begin{array}{l}2.49 \mathrm{a} \\
(2.23)\end{array}$ & $\begin{array}{l}3.04_{b} \\
(2.41)\end{array}$ & $\begin{array}{l}3.53_{c} \\
(2.63)\end{array}$ & $\begin{array}{l}3.34_{b} \\
(2.70)\end{array}$ & $37.1^{\star \star \star}$ \\
\hline
\end{tabular}

Note: Games-Howell post hoc test was used for pairwise comparisons of means. Proportions are compared with z-test. *: $p<0.05$; $* * *: p<0.001$. Cl: confidence interval. Values in the same row not sharing the same subscript are significantly different at $p<0.05$. Analyses are performed with the unweighted dataset. 


\begin{tabular}{|c|c|c|c|c|c|}
\hline & $\begin{array}{l}\text { Class } 1 \text { - } \\
\text { Full } \\
\text { adherence } \\
\mathrm{N}=\mathbf{2 0 3 4}\end{array}$ & $\begin{array}{l}\text { Class 2- } \\
\text { Partial } \\
\text { adherence } \\
\mathrm{N}=2519\end{array}$ & $\begin{array}{l}\text { Class } 3- \\
\text { Limited } \\
\text { adherence } \\
\mathrm{N}=509\end{array}$ & $\begin{array}{l}\text { Class } 4 \text { - } \\
\text { Non- } \\
\text { adherence } \\
\mathrm{N}=174\end{array}$ & $F / X^{2}$ \\
\hline $\begin{array}{l}\text { Number of days left home } \\
\text { for shopping, pharmacy } \\
\text { Mean (SD) }\end{array}$ & $\begin{array}{l}2.65 a \\
(1.61)\end{array}$ & $\begin{array}{l}3.13_{\mathrm{b}} \\
(1.77)\end{array}$ & $\begin{array}{l}3.74_{c} \\
(2.11)\end{array}$ & $\begin{array}{l}3.60_{b} \\
(2.51)\end{array}$ & $66.6^{\text {*** }}$ \\
\hline $\begin{array}{l}\text { Number of days left home } \\
\text { for other reasons }\end{array}$ & $\begin{array}{l}1.58 \mathrm{a} \\
(1.41)\end{array}$ & $\begin{array}{l}1.90_{\mathrm{b}} \\
(1.70)\end{array}$ & $\begin{array}{l}2.30_{\mathrm{c}} \\
(1.95)\end{array}$ & $\begin{array}{l}2.37_{c} \\
(2.21)\end{array}$ & 37.6 *** \\
\hline $\begin{array}{l}\text { Note: Games-Howell post ho } \\
\text { compared with z-test. } * \text { : } p< \\
\text { sharing the same subscript } \\
\text { unweighted dataset. }\end{array}$ & $\begin{array}{l}t \text { was use } \\
\star \star \star: p<0 \\
\text { gnificant }\end{array}$ & $\begin{array}{l}\text { pairwise } \\
\text { Cl: confic } \\
\text { ferent at }\end{array}$ & $\begin{array}{l}\text { oarisons } \\
\text { interval. } \\
5 \text {. Analys }\end{array}$ & $\begin{array}{l}\text { ins. Propo } \\
\text { in the san } \\
\text { performe }\end{array}$ & $\begin{array}{l}\text { ns are } \\
\text { ow not } \\
\text { ith the }\end{array}$ \\
\hline
\end{tabular}

\section{Predictors of non-adherence to prevent SARS-CoV-2 transmission}

Based on our latent class analyses, we merged the two adherent groups (Classes 1 and 2) and the two limited or non-adherent groups (Classes 3 and 4) to perform a hierarchical binary logistic regression analysis in order to predict non-adherence with the distal socio-demographic, and proximal health beliefs variables. We entered the variables in two blocks (see Table 3).

In the first model, only the distal variables were entered. Non-adherence was more likely among males, in younger age groups and in those with less than high school education (see Table 3). Males had 2.5 times higher odds of not following the preventive behaviours, irrespective of the age groups (see Supplementary Table 3). Age between 18 and 29 was found to have 4.3 times higher odds of not performing the preventive behaviours compared to the older group. Having less than high school education increased the odds of non-adherence by $41 \%$. Finally, we also tested that lack of someone in the household who is at risk of developing severe COVID-19 also increased the odds of non-adherence compared to those who have such relatives.

In Model 2, we also added the proximal variables resulting that only perceived severity decreased the odds of being non-adherent. Observing the decrease of the odds ratio of younger age in Model 2 from Model 1 implies that perceived severity may explain partly the link between age and non-adherence.

Table 3. Predictors of non-adherence to preventive behaviours: a binary logistic regression analysis. 


\begin{tabular}{|c|c|c|c|c|}
\hline & \multicolumn{2}{|l|}{ Model 1} & \multicolumn{2}{|c|}{ Model 2} \\
\hline & $\begin{array}{l}\text { Odds } \\
\text { Ratio }\end{array}$ & $95 \% \mathrm{Cl}$ & $\begin{array}{l}\text { Odds } \\
\text { Ratio }\end{array}$ & $95 \% \mathrm{Cl}$ \\
\hline \multicolumn{5}{|l|}{ Sex } \\
\hline Males & $2.53^{\star \star \star}$ & $\begin{array}{l}{[2.15-} \\
2.97]\end{array}$ & $2.37 * * *$ & $\begin{array}{l}{[2.00-} \\
2.80]\end{array}$ \\
\hline Females & Ref. & & Ref. & \\
\hline \multicolumn{5}{|l|}{ Age } \\
\hline $18-29$ years & $4.30 * * *$ & $\begin{array}{l}{[3.30-} \\
5.61]\end{array}$ & $2.87 * \star \star$ & $\begin{array}{l}{[2.14-} \\
3.86]\end{array}$ \\
\hline $30-49$ years & $1.54^{\star \star}$ & $\begin{array}{l}{[1.21-} \\
1.97]\end{array}$ & 1.25 & $\begin{array}{l}{[0.95-} \\
1.63]\end{array}$ \\
\hline $50-64$ years & 1.14 & $\begin{array}{l}{[0.88-} \\
1.48]\end{array}$ & 1.04 & $\begin{array}{l}{[0.79-} \\
1.37]\end{array}$ \\
\hline $65 \leq$ & Ref. & & Ref. & \\
\hline \multicolumn{5}{|l|}{ Education } \\
\hline Less than high school & $1.41 * *$ & $\begin{array}{l}{[1.12-} \\
1.77]\end{array}$ & $1.42^{\star \star *}$ & $\begin{array}{l}{[1.12-} \\
1.81]\end{array}$ \\
\hline High school & 1.17 & $\begin{array}{l}{[0.92-} \\
1.50]\end{array}$ & 1.17 & $\begin{array}{l}{[0.91-} \\
1.50]\end{array}$ \\
\hline College or University & Ref. & & Ref. & \\
\hline \multicolumn{5}{|l|}{ Settlement types } \\
\hline Budapest (capital) & Ref. & & Ref. & \\
\hline County-town & 1.22 & $\begin{array}{l}{[0.96-} \\
1.54]\end{array}$ & 1.18 & $\begin{array}{l}{[0.89-} \\
1.55]\end{array}$ \\
\hline Other city & $1.26 *$ & $\begin{array}{l}{[1.00-} \\
1.58]\end{array}$ & $1.50 * *$ & $\begin{array}{l}{[1.18-} \\
1.90]\end{array}$ \\
\hline Village and smaller settlements & 1.00 & $\begin{array}{l}{[0.77-} \\
1.30]\end{array}$ & $1.31 *$ & $\begin{array}{l}{[1.02-} \\
1.68]\end{array}$ \\
\hline \multicolumn{5}{|c|}{$\begin{array}{l}\text { Having vulnerable family members in the } \\
\text { household }\end{array}$} \\
\hline No & $1.28 * *$ & $\begin{array}{l}{[1.10-} \\
1.49]\end{array}$ & 1.11 & $\begin{array}{l}{[0.94-} \\
1.30]\end{array}$ \\
\hline
\end{tabular}




\begin{tabular}{|c|c|c|c|c|}
\hline & Model 1 & \multicolumn{3}{|c|}{ Model 2} \\
\hline Yes & Ref. & & \multicolumn{2}{|l|}{ Ref. } \\
\hline \multicolumn{5}{|l|}{ Having a chronic illness } \\
\hline No & 1.06 & $\begin{array}{l}{[0.88-} \\
1.27]\end{array}$ & 0.96 & $\begin{array}{l}{[0.91-} \\
1.08]\end{array}$ \\
\hline Yes & Ref. & & Ref. & \\
\hline $\begin{array}{l}\text { Perceived susceptibility of asymptomatic or mild } \\
\text { condition }\end{array}$ & - & & 0.95 & $\begin{array}{l}{[0.87-} \\
1.03]\end{array}$ \\
\hline Perceived susceptibility of severe condition & - & & 0.99 & $\begin{array}{l}{[0.91-} \\
1.08]\end{array}$ \\
\hline Perceived severity & - & & $0.67 * \star \star$ & $\begin{array}{l}{[0.60-} \\
0.75]\end{array}$ \\
\hline \multicolumn{5}{|c|}{$\begin{array}{l}\text { Note: } N=5152 \text {. (missing is } N=102 \text { ). Cl: confidence intervals. } *: p<0.05 ; * *: p<0.01 ; * \star *: p<0.001 \text {. } \\
\text { Boldfaced coefficients are significant at least at } p<0.05 \text {. Binary outcome variable: } 0 \text { : adherent and } 1 \text { : } \\
\text { non-adherent. Analyses are performed with the unweighted dataset. }\end{array}$} \\
\hline
\end{tabular}

\section{Discussion}

It is encouraging that most participants reported adhering to the main preventive behaviours recommended by the public health authorities. However, it is concerning that men throughout the age ranges were less likely to adopt the recommended measures than women, and this applied to all four preventive approaches. Young people were less likely to adopt preventive approaches than those aged 30 years or more, which was related in part to lower perceived susceptibility to a severe COVID-19 illness.

The SARS-CoV-2 incidence rate has remained relatively low in Hungary probably due to forthright decisions to implement broadly-based public health approaches at an early stage. These include measures aimed at spatial distancing and adopting hygienic approaches that were introduced at an early stage of the pandemic. Based on our results, a large proportion of the population adhered to the recommendation of avoiding close contacts and personal hygienic behaviours to control viral transmission. However, not all behaviours were followed equally: using face masks and protective gloves were less common and more variable among people who were inclined to follow all the other protective measures.

In our study, nearly $18 \%$ of the sample was identified as non-adherent or have limited adherence to the public health recommendations. Non-adherence rates in lifestyle-related behaviour change advice are around $30 \%$ (19). The non-adherence rates reported in the present study are therefore lower but are more concerning because of the implications for imminent morbidity and mortality. Nearly $20 \%$ of persons in the present study reported a low level of adherence to spatial distancing, face mask use and/or taking personal hygienic precautious, thus they have an increased risk of contracting and transmitting the SARS- 
CoV-2 virus and other respiratory infections in the future. At the time when countries try to relax the tight control over virus transmission, it becomes even more important to know the proportion of non-adherent individuals and the predictors of response to preventive advice.

Several countries have experienced higher rates of severe COVID-19 illness and deaths among men compared with women $(11,12,20)$. This should be compared with the data from the present study of male gender being another important predictor of non-adherence. An increased risk of death among males was documented in relation to the previous SARS-virus induced acute respiratory syndrome, in which males had $66 \%$ higher risk of dying than females(21). Several hypotheses have been proposed to explain this gender difference, including different rates of smoking $(22,23)$. Our data highlight the gender difference in adherence to preventive behaviours. Since we do not have data about the smoking status of our participants we cannot control for the covariance between smoking and non-adherent behaviours. Previous studies also supported the gender disparities in handwashing behaviour and knowledge regarding personal hygienic behaviours $(24,25)$. However further research is necessary to disentangle the multiple behavioural mechanisms that can explain why males seem to be more vulnerable to respiratory infections. We also need research on the gendered meaning of preventive behaviours that would explain the lower rate of preventive behaviours among men(26).

Being of a younger age is an important predictor of non-adherence to preventive behaviours. Frequent communication regarding the SARS-CoV-2 virus stressed the fact that COVID-19 threatens mainly the older population. This can lead to a false safety message to younger people(27), though $1 \%$ of hospitalization due to COVID-19 in China was among those aged $20-29$ years, and $3 \%$ from the age group of 30-39 years old(28).

Our study demonstrated different rates of preventive behaviours. The variance of the use of physical barriers may be due to several factors including (1) the lack of practice of face mask use; (2) the social meaning of face masks and gloves in Europe; and (3) messages from the WHO and the country's officials regarding the use of face masks and protective gloves (WHO, 2020). However, previous experience with prevention of influenza emphasized the use of face mask with hand hygienic measures (8). It is important to note that face mask use did not decrease the frequency of the use of other preventive techniques, therefore it did not increase illusory safety. It can be recommended without the serious side effect of neglecting other infection control means. Furthermore, recent evidence supports the idea that face mask can protect from the transmission of viral RNA (29).

Our study is not without limitations. The cross-sectional design does not allow definitive conclusions about causation, and self-reported data may be distorted by social desirability bias. An independent direct observational study could validate our findings. However, in the present pandemic there is a compelling need for timeliness of studies. Understanding adherence to public health recommendations will help decreasing the likelihood of SARS-CoV-2 transmission and potentially the severity of the COVID-19 illness, and should help us in the future to prevent and contain influenza and other still unknown viral pandemics. Everyone, irrespective of their particular risk of these infections, can contribute to the health 
of the community as a whole. The findings from the present study emphasize that developing ways of engaging men, young people and those of low socioeconomic status in adopting preventive behaviours and emphasising the severity of the illness is vital not only for optimal prevention of SARS-CoV-2 transmission now and in the future, but also for effective control of related respiratory infections.

\section{Declarations}

\section{Ethics Approval and Consent to participate}

Participation of this study was anonymous and voluntary. The participants were requested to construct a code which made it possible to contact them later for a possible follow-up data-collection. This research was performed in accordance with Helsinki declaration. This study protocol was approved by the Institutional Review Board of Eötvös Loránd University, Budapest, Hungary (no: 2020/134). Informed consent was obtained from all participants.

\section{Consent for Publication}

Not applicable.

\section{Availability of Data and Materials}

The dataset used and analysed in this study is available from the corresponding author on reasonable request.

\section{Competing Interests}

None of the Authors declared any conflict of interest.

\section{Funding}

The study was supported by the National Research, Development and Innovation Office (NKFIH-11578/2019-DT). The funding institution had no role in the study design or the collection, analysis and interpretation of the data, writing the manuscript, or the decision to submit the paper for publication. The authors had full access to the data and take responsibility for the integrity of the data and the accuracy of the data analysis.

\section{Author Contributions}

The author contributions: Literature search (R. U.), study design (R.U., B.P., A.M., Zs.D.), data collection (B.P., Zs.D.), data analysis and interpretation (R.U., A.M., J.B.S., Zs.D.), writing (R.U., B.P., A.M., J.B.S., Zs.D).

\section{Acknowledgements}

Not applicable. 


\section{References}

1. Bavel JJV, Baicker K, Boggio PS, Capraro V, Cichocka A, Cikara M, et al. Using social and behavioural science to support COVID-19 pandemic response. Nat Hum Behav. 2020 May;4(5):460-71.

2. West R, Michie S, Rubin GJ, Amlôt R. Applying principles of behaviour change to reduce SARS-CoV-2 transmission. Nat Hum Behav. 2020 May;4(5):451-9.

3. Zheng J. SARS-CoV-2: an Emerging Coronavirus that Causes a Global Threat. Int J Biol Sci. 2020;16(10):1678-85.

4. Rothe C, Schunk M, Sothmann P, Bretzel G, Froeschl G, Wallrauch C, et al. Transmission of 2019nCoV Infection from an Asymptomatic Contact in Germany. N Engl J Med. 2020 Mar 5;382(10):9701.

5. Alimohamadi Y, Taghdir M, Sepandi M. The Estimate of the Basic Reproduction Number for Novel Coronavirus disease (COVID-19): A Systematic Review and Meta-Analysis. J Prev Med Pub Health [Internet]. 2020 Mar 20 [cited 2020 May 2]; Available from: http://jpmph.org/journal/view.php? doi=10.3961/jpmph.20.076

6. Anderson RM, Heesterbeek $\mathrm{H}$, Klinkenberg D, Hollingsworth TD. How will country-based mitigation measures influence the course of the COVID-19 epidemic? The Lancet. 2020 Mar;395(10228):931-4.

7. Abel T, McQueen D. The COVID-19 pandemic calls for spatial distancing and social closeness: not for social distancing! Int J Public Health. 2020 Apr;65(3):231-231.

8. Wong VWY, Cowling BJ, Aiello AE. Hand hygiene and risk of influenza virus infections in the community: a systematic review and meta-analysis. Epidemiol Infect. 2014 May;142(5):922-32.

9. Cheng KK, Lam TH, Leung CC. Wearing face masks in the community during the COVID-19 pandemic: altruism and solidarity. The Lancet [Internet]. 2020 Apr [cited 2020 May 2]; Available from: https://linkinghub.elsevier.com/retrieve/pii/S0140673620309181

10. Feng S, Shen C, Xia N, Song W, Fan M, Cowling BJ. Rational use of face masks in the COVID-19 pandemic. Lancet Respir Med [Internet]. 2020 Mar [cited 2020 May 2]; Available from: https://linkinghub.elsevier.com/retrieve/pii/S221326002030134X

11. Petrilli CM, Jones SA, Yang J, Rajagopalan H, O'Donnell LF, Chernyak Y, et al. Factors associated with hospitalization and critical illness among 4,103 patients with COVID-19 disease in New York City [Internet]. Intensive Care and Critical Care Medicine; 2020 Apr [cited 2020 May 2]. Available from: http://medrxiv.org/lookup/doi/10.1101/2020.04.08.20057794

12. Guan W, Ni Z, Hu Y, Liang W, Ou C, He J, et al. Clinical Characteristics of Coronavirus Disease 2019 in China. N Engl J Med. 2020 Apr 30;382(18):1708-20.

13. Bertocchi G. COVID-19 susceptibility, women, and work [Internet]. VoxEU.org. 2020 [cited 2020 May 2]. Available from: https://voxeu.org/article/covid-19-susceptibility-women-and-work

14. Dorn A van, Cooney RE, Sabin ML. COVID-19 exacerbating inequalities in the US. The Lancet. 2020 Apr;395(10232):1243-4. 
15. Glanz K, Bishop DB. The Role of Behavioral Science Theory in Development and Implementation of Public Health Interventions. Annu Rev Public Health. 2010 Mar;31(1):399-418.

16. de Zwart O, Veldhuijzen IK, Elam G, Aro AR, Abraham T, Bishop GD, et al. Perceived Threat, Risk Perception, and Efficacy Beliefs Related to SARS and Other (Emerging) Infectious Diseases: Results of an International Survey. Int J Behav Med. 2009 Mar;16(1):30-40.

17. Collins LM, Lanza ST. Latent class and latent transition analysis: with applications in the social behavioral, and health sciences. Hoboken, N.J: Wiley; 2010. 285 p. (Wiley series in probability and statistics).

18. Muthén LK, Muthén BO. Mplus User's Guide. Eighth Edition. Los Angeles, CA: Muthén \& Muthén; 1998.

19. DiMatteo MR. Variations in Patients??? Adherence to Medical Recommendations: A Quantitative Review of 50 Years of Research. Med Care. 2004 Mar;42(3):200-9.

20. Zhou F, Yu T, Du R, Fan G, Liu Y, Liu Z, et al. Clinical course and risk factors for mortality of adult inpatients with COVID-19 in Wuhan, China: a retrospective cohort study. The Lancet. 2020 Mar;395(10229):1054-62.

21. Karlberg J. Do Men Have a Higher Case Fatality Rate of Severe Acute Respiratory Syndrome than Women Do? Am J Epidemiol. 2004 Feb 1;159(3):229-31.

22. Cai H. Sex difference and smoking predisposition in patients with COVID-19. Lancet Respir Med. 2020 Apr;8(4):e20.

23. Vardavas C, Nikitara K. COVID-19 and smoking: A systematic review of the evidence. Tob Induc Dis [Internet]. 2020 Mar 20 [cited 2020 May 2];18(March). Available from: http://www.journalssystem.com/tid/COVID-19-and-smoking-A-systematic-review-of-theevidence,119324,0,2.html

24. Mariwah S, Hampshire K, Kasim A. The impact of gender and physical environment on the handwashing behaviour of university students in Ghana: Impact of gender and environment on hygiene behaviour. Trop Med Int Health. 2012 Apr;17(4):447-54.

25. Suen LKP, So ZYY, Yeung SKW, Lo KYK, Lam SC. Epidemiological investigation on hand hygiene knowledge and behaviour: a cross-sectional study on gender disparity. BMC Public Health [Internet]. 2019 Dec [cited 2020 May 2];19(1). Available from: https://bmcpublichealth.biomedcentral.com/articles/10.1186/s12889-019-6705-5

26. Addis ME, Mahalik JR. Men, masculinity, and the contexts of help seeking. Am Psychol. 2003;58(1):5-14.

27. Kluge HH. Statement - Older people are at highest risk from COVID-19, but all must act to prevent community spread [Internet]. World Health Organization; 2020 [cited 2020 May 2]. Available from: http://www.euro.who.int/en/health-topics/health-emergencies/coronavirus-covid19/statements/statement-older-people-are-at-highest-risk-from-covid-19,-but-all-must-act-to-preventcommunity-spread 
28. Ruan S. Likelihood of survival of coronavirus disease 2019. Lancet Infect Dis [Internet]. 2020 Mar [cited 2020 May 2]; Available from: https://linkinghub.elsevier.com/retrieve/pii/S1473309920302577 29. Leung NHL, Chu DKW, Shiu EYC, Chan K-H, McDevitt JJ, Hau BJP, et al. Respiratory virus shedding in exhaled breath and efficacy of face masks. Nat Med [Internet]. 2020 Apr 3 [cited 2020 May 2]; Available from: http://www.nature.com/articles/s41591-020-0843-2

\section{Figures}

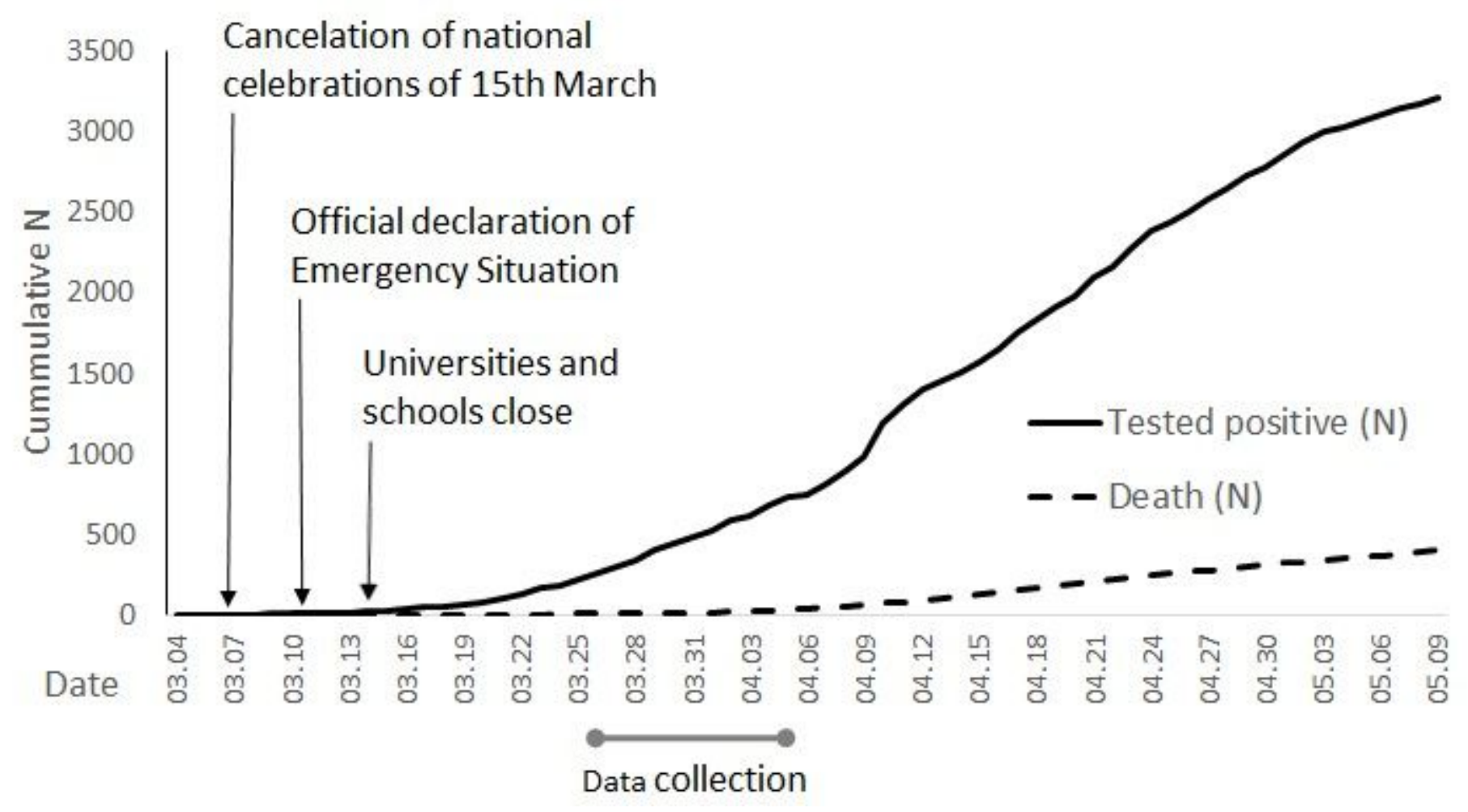

Figure 1

SARS-CoV-2 pandemic context of present data collection. 


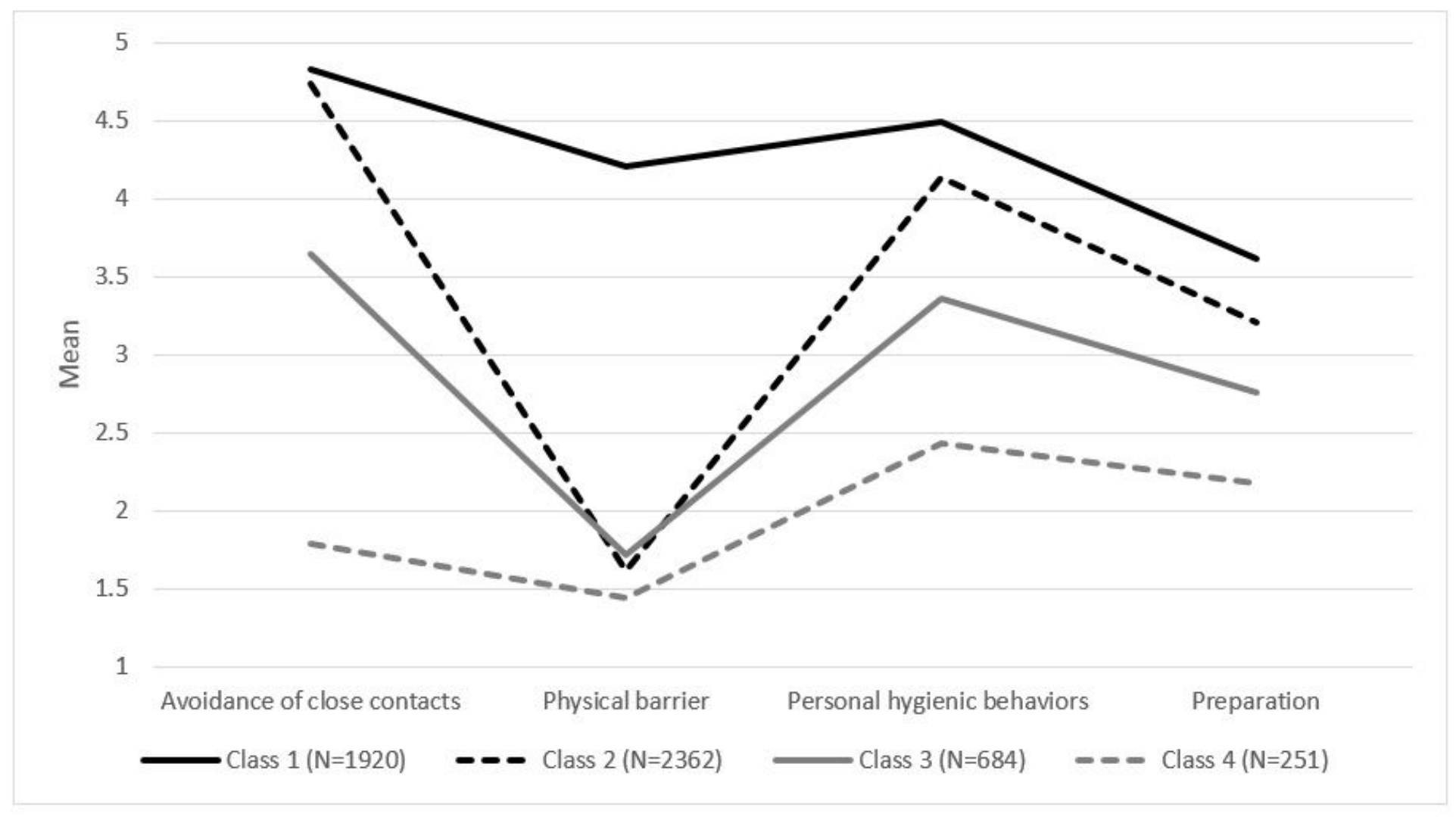

\section{Figure 2}

Latent profile analysis: Classification of adherence to protective behaviours. Note: The sizes of latent classes are estimated with the use of sampling weights. Unweighted frequencies were: Class 1 (Full adherence): $\mathrm{N}=2034$; Class 2 (Partial adherence): $\mathrm{N}=2519$; Class 3 (Limited adherence): $\mathrm{N}=509$; Class 4 (Non-adherent): $\mathrm{N}=174$. The range of means is between 1 (never) and 5 (always).

\section{Supplementary Files}

This is a list of supplementary files associated with this preprint. Click to download.

- Supplementarytables.docx 